\title{
Ukraine's Cultural Diplomacy in the Black Sea Region
}

\author{
Svitlana Ovcharenko ${ }^{1}$ \\ ${ }^{1}$ Doctor of Science in Philosophy. Full Professor at Odesa Regional Institute for Public Administration of the National \\ Academy for Public Administration under the President of Ukraine, Odesa, Ukraine. \\ https://orcid.org/0000-0002-3311-1546
}

Correspondence: Svitlana Ovcharenko, Odesa Regional Institute for Public Administration of the National Academy for Public Administration under the President of Ukraine, Genuezskaya str., Odessa, Ukraine, 65009.

E-mail: ovcharenkosvtln@oridu.odessa.ua

Received: May 6, $2021 \quad$ Accepted: August 21, $2021 \quad$ Online Published: September 7, 2021

doi:10.11114/ijlpa.v4i2.5228 URL: https://doi.org/10.11114/ijlpa.v4i2.5228

\begin{abstract}
The article analyzes the achievements, prospects and issues of Ukrainian cultural diplomacy in the Black Sea region. It outlines different levels of cultural cooperation in the region, in which the goals of Ukraine's cultural diplomacy can be realized: cooperation within UNESCO, cooperation within the Eastern European Partnership, cooperation within the Black Sea Economic Cooperation (BSEC), cooperation within bilateral cultural contacts. It is emphasized that all formats of cultural interaction complement each other and can have a synergistic effect. It is noted that Ukraine is one of the few countries that has participated in the ICDS testing, and together with Georgia, Armenia and Azerbaijan can set a precedent for the regional application of this methodology by UNESCO. Ukrainian cultural diplomacy in the Black Sea region is also considered in connection with the state's European integration obligations under the "Association Agreement between Ukraine and the EU". Summarizing the level of activity in the field of cultural diplomacy in the region, it is noted that Ukraine is not fully aware of the importance of cultural diplomacy tools for resolving the conflict situation related to the occupation of the Crimean Peninsula by the Russian Federation. Examining the content of the "Strategy of Public Policy of the Ministry of Foreign Affairs of Ukraine 2021-2025", a recommendation was made to supplement the list of target regions for cultural diplomacy of Ukraine with the Black Sea region as an integral socio-cultural object.
\end{abstract}

Keywords: cultural diplomacy, cultural policy, Black Sea region.

\section{Introduction}

In recent years, the events in the Black Sea have often attracted the attention of the international political community and are linked to the theme of preserving peace in the region. The Black Sea has been a zone of heightened uncertainty since the Russian Federation annexed the Crimean Peninsula. For Ukraine, this has been a challenge in many respects, one of which is the aspect of cultural self-determination as a maritime state.

The image of Ukraine as a state closely connected with the sea is not rooted in the mythological narrative of national self-consciousness. In traditional folklore, Ukrainians are represented as a people of steppe, rivers, forests and mountains, with this natural context associated with the formation of the Ukrainian ethnic group and the Ukrainian nation. However, as a modern state, Ukraine owns a significant share of the Black Sea coast and is often referred to in today's world political discourse as a state with a maritime conflict - the annexation of Crimea. This conflict sharply raises the question of maintaining free maritime trade and fishing in the Black Sea, which can prevent the presence of the Russian navy on the bases of the Crimean Peninsula. Meanwhile, Ukraine's constant reminder of unresolved socio-political problems in the Black Sea region in the political consciousness of the world and local community clearly captures the modern idea of Ukraine's state space as a country fully present in the Black Sea region and claims international recognition as a leading maritime state. But in today's world there is a complex interaction between the cultural image of the country and its political and economic positioning, which should be taken into account by the Ukrainian government, which shapes the policy of Ukraine's presence in the Black Sea basin. 
At the beginning of 2021, significant events took place and significant statements were made in the field of Ukrainian public administration, which determine the relevance of the topic that will be discussed in this article - the development of cultural diplomacy in the Black Sea region.

It should be noted that the Ministry of Foreign Affairs of Ukraine has made a loud statement about the country's desire to compete for the position of head of the Organization of the Black Sea Economic Cooperation (BSEC). In the interview with the leading Ukrainian news agency UKRINFORM on January 27, 2021, Deputy Minister of Foreign Affairs Vasyl Bondar stressed that "Ukraine continues to fight for the post of BSEC Secretary General", whose election is to take place in May this year.

The BSEC was established as an organization to promote regional cooperation in the Black Sea basin. The Founding Members of the Black Sea Economic Cooperation - the Republic of Albania, the Republic of Armenia, the Republic of Azerbaijan, the Republic of Bulgaria, Georgia, the Hellenic Republic, the Republic of Moldova, Romania, the Russian Federation, the Republic of Turkey, and Ukraine, these are the countries that signed on 25 June 1992 in Istanbul the «Summit Declaration on Black Sea Economic Cooperation».

As we can see, Ukraine was one of the founders of the organization and later took an active part in all formats of BSEC activities. At the current stage of cooperation with the BSEC, the adoption of the Law of Ukraine on Ratification of the Amendment to Article 24 of the Charter of this organization, which in 2004 introduced the International Center for Black Sea Studies with the right to have offices in member countries, adds importance to Ukraine's proactive stance. The announcement appeared on the official website of the President of Ukraine on March 23, 2021. The article states: "The International Center for Black Sea Studies (ICBSS) is an international organization that acts as an analytical center of the BSEC Organization and is headed by a Board of Directors whose members are citizens of the BSEC member states.

The main objectives of the ICBSS are to explore practical ways to expand and deepen regional cooperation between the BSEC member states, relations between the BSEC and the EU, and to promote the application of science and technology in specific areas of multilateral cooperation based on the principles of this Statute and priorities".

Among the scientific and analytical areas that can be taken care of by the ICBSS in Ukraine, issues of cultural and social cooperation in the region may be important, the study of which will promote harmony and understanding among the member states of the Black Sea Commonwealth. Today, such an acute issue for the region, which is important for the political stability of the whole spectrum of relations in the Black Sea basin, is the issue of cultural identification of Crimea. An unbiased international discussion on the historical and cultural features of this territory could contribute to peace in the Black Sea because of its historical and cultural arguments that publicly justify the violation of international law by the Russian Federation regarding this territory.

The actualization of interest in the topic of cultural diplomacy in the Black Sea region is also connected with an important event for understanding the changes taking place in public administration of Ukraine, which took place in early 2021 - the presentation of "Public Diplomacy Strategy of the Ministry of Foreign Affairs of Ukraine for 2021-2025". In fact, this is the first comprehensive document of this content, which demonstrates the state's awareness of the importance of informal diplomatic sources for the development of interstate relations and international communication. An important role in this process should be played by the sphere of culture, the goals and objectives of which are emphasized in this strategy: "Cultural diplomacy is one of the areas of public diplomacy and soft power policy aimed at improving the visibility of Ukraine and its cultural diversity, formation of a positive attitude of citizens of other countries to Ukraine. Cultural diplomacy as a direction of foreign policy makes it possible to promote and share national achievements and experiences in the field of culture with citizens of other countries, achieving better understanding and trust ".

The strategy also defines the ways in which Ukraine's intentions in the field of cultural diplomacy are to be realized:

"1) promotion of modern Ukrainian cinema, especially promotion and participation of Ukrainian films in international film festivals;

2) promotion of modern Ukrainian classical and popular music, promotion of joint international projects;

3) promotion of modern Ukrainian theater and performative art, in particular through participation in international theater festivals;

4) promotion of modern Ukrainian literature, promotion of participation of Ukraine in the leading international book exhibitions, assistance in translation and publication of works by Ukrainian writers abroad or across the border:

5) promotion of publishing projects for publication by foreign countries languages of books and brochures to promote the history and present of Ukraine;

6) promotion of Ukrainian classical and modern visual art, in particular through exhibition projects abroad or across the border, artistic exchanges and collaborations; 
7) promoting the promotion of Ukrainian creative industries, in particular design, fashion, architecture, etc.;

8) presentation of the diversity of Ukrainian art, in particular presentation of Ukrainian culture and art in the framework international festivals, forums, conferences;

9) promotion of international research projects in the field culture and art, encouraging foreign professionals to study Ukrainian culture;

10) promotion of Ukrainian cultural heritage;

11) popularization of the Ukrainian language in the world;

12) promotion of projects in the field of culture and art of representatives indigenous peoples and national minorities ".

Summarizing this list of possible directions of the international presence of Ukrainian culture, we emphasize the significant attention to joint international projects - festivals, forums, conferences. The Black Sea community as a regional center for these forms of activity is a natural environment for cultural collaboration. However, unfortunately, in the text of the Strategy we do not find a mention of this region as a holistic space for the application of public diplomacy. Section Six of the Strategy, which identifies priority territorial areas for Ukraine's foreign policy, mentions cultural diplomacy, but it is understood as a priority of the Ukrainian Institute, which began in 2017 and aims to develop Ukrainian cultural diplomacy. These countries "for cultural diplomacy are the United States, Canada, Great Britain, the Netherlands, France, Germany, Poland, Lithuania, Italy, Austria, Hungary, Serbia, Turkey, Israel, Qatar, UAE, China, Japan (geography of the Ukrainian Institute)".

Given the difficult military-political situation in the Black Sea, which emerged as a result of the annexation of Crimea, the lack of individual countries of the Black Sea Commonwealth and the whole region in its political and geographical definition, as a priority object for the widest range of diplomatic activities to consider a certain strategic shortcoming of the Ukrainian state position. Perhaps this is due to the difficulty of Ukraine's cultural self-identification as a maritime state, which has already been discussed. But such a situation requires scientific analysis and further discussion in the context of those issues that can be answered by expanding regional cooperation in the field of culture.

Thus, the purpose of this study will be to analyze the achievements and prospects of cultural diplomacy of Ukraine in the Black Sea region, which can contribute to the development of all aspects of cultural diplomacy between the countries of the Black Sea Commonwealth.

The study of the directions of possible deepening of the efforts of the cultural diplomacy of Ukraine in the Black Sea region will be based on the methodological approach, which takes into account the multilayered cultural ties between the countries that form the regional integrity.

It can be stated that international cooperation in the field of culture in the Black Sea region is due to several formats at once:

1. Global international cooperation;

2. European international cooperation;

3. Regional international cooperation;

4. Binary interstate international cooperation.

However, all of these formats are interrelated and complementary, although this is not self-evident and requires further analysis.

As a result, we get an idea of the complex network of relations between the Black Sea countries in the field of cultural diplomacy, which is determined by participation in various programs, using different sources of funding for cultural events, joining various cultural alliances and implementing common cultural goals through various instruments. Such cultural synergy should be taken into account in the further development of theoretical foundations and practical actions in the formation of state policy on cultural diplomacy of Ukraine in the Black Sea region.

\section{Global Level of Cultural Cooperation between the Countries of the Black Sea Basin}

The global level of cultural diplomacy in the Black Sea region is represented by the implementation of declarations and conventions jointly adopted and ratified by UN member states, which are monitored by UNESCO. Sharing the common values and intentions of the United Nations in the field of culture, the countries of the Black Sea Basin in their joint statements on cultural policy and in the cultural policy of each country in the region declare their commitment to UNESCO's cultural strategies. This will facilitate regional coordination of efforts to preserve regional cultural heritage and promote the development of cultural industries at the regional and local levels. 
The fundamental political documents that organize cultural interaction within the framework of global international cooperation at the present stage, including between the countries of the Black Sea basin, are two UN conventions:

1) Convention for the Protection and Promotion of the Diversity of Cultural Expressions (2005);

2) Convention for the Safeguarding of the Intangible Cultural Heritage (2003).

These conventions have been ratified by all countries in the region and can be considered the basis of a modern worldview approach to cultural policy in each country, which, of course, unites and becomes the basis for cultural interaction in the region.

In the modern world, which is on the verge of global political and economic transformations, none of the events is discussed without mentioning the factor of culture in two aspects at once - as their basis and as their ultimate goal. Modern political and economic processes, including, of course, both the processes of globalization and the processes of regionalization, are no longer thought of outside the cultural context. That is why, when considering the cultural aspects of interaction between the countries of the Black Sea region, one cannot ignore those initiatives in which these countries take part, sharing the humanitarian and cultural goals of the UN and UNESCO. Although each country bears personal responsibility for the results of its activities in the context of global cultural cooperation, their achievements are also important for the sustainable cultural development of the Black Sea basin.

At the modern stage of the development of cultural diplomacy, the countries of the Black Sea region have something to share with each other not only in the process of direct exchange of the achievements of art - modern or traditional, but also in the process of organizing the management of cultural processes. In realizing its tasks of cultural diplomacy, Ukraine should strive to become a full-fledged participant in programs that create a single context for cultural interaction in the region, and in some cases, take the initiative to create new opportunities in this area.

Information on the degree of involvement of the countries of the Black Sea basin in global cultural processes can be obtained by analyzing data on the official websites of UNESCO.

For example, such countries of the Black Sea Commonwealth as Armenia and Azerbaijan are the most active participants in various UNESCO programs, and in June 2019, representatives of these countries were included in the new composition of the Intergovernmental Committee of UNESCO on monitoring the implementation of the Convention on Diversity.

Armenia and Azerbaijan are also active participants in UNESCO's programs for the protection and preservation of intangible cultural heritage. Such countries of the Black Sea region as Romania, Turkey, Bulgaria share their interest in this topic and are actively involved in various collective actions of UNESCO for the preservation of cultural heritage, while Ukraine, Moldova, Georgia are not represented in the UNESCO working groups on these issues. At the same time, it should be noted with regret that the real state of affairs with the protection of intangible cultural heritage in Ukraine is not the best, although recently significant steps have been taken to develop cooperation with the world community in this matter.

But Ukraine is among the few countries that took part in approbation of the methodology for monitoring the state of culture in the country based on the UNESCO Culture for Development Indicators. In 2017, Ukraine presented "UNESCO CULTURE FOR DEVELOPMENT INDICATORS. Ukraine's Technical Report".

If we take into account that three more countries of the Black Sea region have submitted their national reports on this system - Armenia, Azerbaijan and Georgia, it can be argued that the Black Sea community has a unique regional experience in using this system of assessing the state of culture in the state, which it can enrich other regions in our global world.

UNESCO Culture for Development Indicators (ICDS) was formed in 2014 and initially tested in 12 countries, the survey experience of which was generalized to improve the system of quantitative and qualitative monitoring of the impact of culture on the general social and economic development of the state. These indicators were developed during 2008-2012, mainly for low- and middle-income countries, to show the role of culture in their development, but further improvement of this system requires the accumulation of data from a wide range of countries.

The system consists of 22 indicators, systematized in 7 areas: 1) Economy; 2) Education: 3) Governance; 4) Social; 5) Gender; 6) Communication; 7) Heritage. The application manual for this system explains the purpose of each of these indicators as follows:

“- Economy: That measure the contribution of the culture sector to economic development and its potential for growth

- Education: That measure the priority given by public authorities to support an education system that offers the broadest possible coverage, values diversity and openness, and promotes a competitive and creative class 
- Governance: That measure the public commitment towards creating the conditions to structure the cultural sector, strengthen cultural processes, and promote diversity of views and voice

- Social participation: That measure the way in which cultural practices, values and attitudes may orient behavior, inclusion, cooperation and individual empowerment

- Gender Equality: That measure the objective and subjective gaps between women and men in their opportunities and rights to take part in cultural social, economic and political life

- Communication:That measure the conditions of access, enjoyment of diverse content and freedom of expression

- Heritage: That measure the public commitment to set up and enforce standards, policies and measures to protect and promote heritage, while ensuring access and sustainability".

The dissemination of the experience of working with these indicators from Ukraine, Georgia, Azerbaijan, Armenia to other countries of the Black Sea basin could contribute to expanding the evidence base for the relationship of cultural processes with the general processes of social, economic and political development of different countries. In particular, cooperation in the field of cultural research at the regional level could contribute to the refinement of indicative parameters, taking into account the local specifics of cultural processes. This could be a real regional project for solving global problems, which UNESCO calls for joint solution. The authors of the ICDS methodology see further steps for the development of the system as follows:

“- expanding the number of countries covered in order to enrich the Global CDIS Database and to allow further analysis;

- refining the systems of visualization to assist in analysis of the data, and to facilitate awareness-raising and policy-making initiatives;

- improving the system of indicators in order to enlarge the dimensions covered, multiply benchmark indicators and to allow investigation of correlations/causalities between variables;

- adapting the indicators to regional and local level;

- identifying core cultural indicators to be included in global instruments of measurement of development.

Thus, one of the possible directions for the development of cultural diplomacy for Ukraine in the Black Sea region may be closer cooperation with Armenia, Azerbaijan and Georgia in continuing a research experiment to introduce permanent monitoring of the state of culture in the region based on ICDS.

\section{Cultural Diplomacy in the Black Sea Region in the Context of Ukraine's European Integration Expectations}

The countries of the Black Sea basin form a kind of regional configuration, in which each country is represented differently in the joint cultural programs of UNESCO and differently involved in the cultural programs of the EU.

As already mentioned, the Convention for the Protection and Promotion of the Diversity of Cultural Expressions (2005) and the Convention for the Safeguarding of the Intangible Cultural Heritage (2003) are today a common modern worldview framework for the Black Sea region. The same conventions are repeatedly mentioned in the documents of the European Union, which determine the strategies of its cultural development. For this reason, they can be considered as framework documents that unite global and local levels of cultural cooperation between the countries of the Black Sea region, including within the framework of the Eastern European Partnership programs. Ukraine is actively cooperating with this program, within the framework of which it also interacts with the countries of the Black Sea region.

At the international level, the processes in culture are today considered as a reflection of the general political and economic state of an individual country and the world as a whole. The state of culture can be an indicator of attitudes towards human rights and openness of society, towards issues of gender equality, towards development opportunities for young people and freedom of movement. The state of culture affects the ways and speed of solving problems with environmental pollution, affects the level of readiness to adopt innovative technologies to solve these issues.

The main provisions of the Convention on Cultural Diversity and the Convention for the Protection of the Intangible Cultural Heritage were taken into account in the formation of the Lisbon Treaty, as a result of which in 2009 such countries of the Black Sea regional community as Bulgaria and Romania became members of the European Union. In the 13th chapter "Culture" of this Treaty (Article 167 (ex Article 151 TEC)) we find the following principles that form the strategy of cultural development for the countries of the European Union and apply to their external relations with other countries in this area:

'1. The Union shall contribute to the flowering of the cultures of the Member States, while respecting their national and regional diversity and at the same time bringing the common cultural heritage to the fore. 
2. Action by the Union shall be aimed at encouraging cooperation between Member States and, if necessary, supporting and supplementing their action in the following areas:

- improvement of the knowledge and dissemination of the culture and history of the European peoples,

- conservation and safeguarding of cultural heritage of European significance,

- non-commercial cultural exchanges,

- artistic and literary creation, including in the audiovisual sector.

3. The Union and the Member States shall foster cooperation with third countries and the competent international organizations in the sphere of culture, in particular the Council of Europe.

4. The Union shall take cultural aspects into account in its action under other provisions of the Treaties, in particular in order to respect and to promote the diversity of its cultures.

In fact, the text of the Lisbon Treaty enshrines not only the basic principles of cultural policy and understanding of the role of culture, formed at the UN level, but also the main tasks and principles of the ENI (European Neighborhood Instruments) program, which was formed 2 years earlier - in 2007. The EU's Program for the promotion and development of Eastern Partnership is based on the same principles of promoting cultural diversity, promoting creativity, cultural exchanges and preserving cultural heritage. It should be borne in mind that the state of culture in European countries is also influenced by general political principles - democracy and decentralization of cultural activity, freedom of creativity, observance of the right to choose ethnic and religious identity, the right to freedom of information and communication, the right to accessibility of education, in including in the field of culture.

These general political norms are reflected in the articles of the «Association Agreement between the European Union and Ukraine», dedicated to the development of culture. This is evidence that Ukraine's European integration aspirations must be realized not only in the system of organizing the political and economic situation in the country, but also in the coherence of cultural policy with the countries of the European Community. The Agreement entered into force in full after the end of the ratification procedure by all EU countries only in September 2017, although it was signed on March 21, 2014, which means that all EU strategic plans related to culture must be supported by Ukraine.

Chapter 24 of the Agreement explicitly states that the parties should promote cultural cooperation, striving to implement the principles set forth in the UN Conventions in 2003 and 2005:

"Article 437. The Parties shall undertake to promote cultural cooperation in order to enhance mutual understanding and foster cultural exchanges, as well as to boost the mobility of art and artists from the EU and Ukraine.

Article 438. The Parties shall encourage intercultural dialogue between the individuals and organizations representing organized civil society and cultural institutions in the EU and in Ukraine.

Article 439. The Parties shall closely cooperate in relevant international fora, including United Nations Educational, Scientific and Cultural Organization (UNESCO) and the Council of Europe (CoE), inter alia, in order to develop cultural diversity, and to preserve and valorize cultural and historical heritage.

Article 440. The Parties shall endeavor to develop a regular policy dialogue on culture in order to foster the development of cultural industries in the EU and in Ukraine. To this end, the Parties shall implement properly the UNESCO Convention on the Protection and Promotion of the Diversity of Cultural Expressions of 2005.

Coordinating its actions with the EU in the field of culture, Ukraine should be included in the events and programs that the European Community has adopted in recent years, shaping the agenda for the period up to 2030. Culture in this process of integral social development of the EU countries takes a significant place as one of the aspects of the "UN Development Goals 2016-2030" implementation.

One such documents is the" New European Agenda for Culture", which was adopted in 2018. This document builds on the ideas outlined in the "European Agenda for Culture in a Globalizing World from 2007". From the title of the 2007 document, it is clear that Europe tried to comprehend its unique place in globalization processes. And we especially emphasize that this document preceded the final formation of the Lisbon Treaty and shows that the search for a balance between civilizational identity and openness to global cultural processes is important for the European Community. The expansion of the borders of the European Union, the implementation of the policy of good neighborliness is also understood as a constant intercultural dialogue, a constant search for mutual understanding in the cultural sphere, which should be taken into account by Ukraine in its intentions of cultural diplomacy.

The «New European Agenda for Culture 2018» contains direct recommendations for building a foreign policy in the field of culture, which should contribute to strengthening international cultural cooperation:

“- Support culture as an engine for sustainable social and economic development 
- Promote culture and intercultural dialogue for peaceful inter-community relations - Reinforce cooperation on cultural heritage"

This document refers to an earlier document that was adopted in 2016 - "Towards an EU strategy for international cultural relations". International cultural relations, according to the vision of their development strategy, should be based on the following principles:

“(a) Promote cultural diversity and respect for human rights

(b) Foster Mutual Respect and Inter-Cultural Dialogue

(c) Ensure respect for Complementarity and Subsidiarity

(d) Encourage a cross-cutting approach to culture

(e) Promote culture through existing frameworks for cooperation.

The implementation of these principles is supposed to be carried out through the following programs: Partnership Instrument (PI), European Instrument for Democracy and Human Rights (EIDHR), The Global Public Goods and Challenges Program under the Development Cooperation Instrument (DCI), Instrument contributing to Stability and Peace (IcSP), Creative Europe Program.

The EU's plans to use the potential of culture in building friendly partnerships with its closest neighbors and the whole world can be characterized as systemic and deeply thought-out. These plans take into account the specifics of the regions, the real level of involvement of prospective partners in world and regional cultural processes, the economic and political situation of states. The EU builds its cultural policy, relying on common humanistic principles and finding individual tools to strengthen relations both within the European Community and beyond.

"Towards the EU strategy for international cultural relations" contains section Three "Advancing cultural cooperation with partner countries", which specifically mentions the role of the cultural component in ensuring the success of the implementation of the Eastern European Partnership program. This program assumes that "cooperation, dialogue and mobility amongst cultural operators, artists are key aspects of inter-cultural dialogue. The circulation of works of art and cultural productions between countries spreads new ideas, establishes direct and indirect ties, and fosters innovation. Strengthened cultural cooperation with the EU's partners can help open the 'European cultural space' to new cultural players and audiences". Building on the success of the first period of the program, which lasted from 2011-2015, it is proposed to continue cooperation in this format: “...the Eastern Partnership Culture Program II (involving Armenia, Azerbaijan, Belarus, Georgia, Moldova and Ukraine) will further develop the cultural operators' skills and capacities during a three-year period. It seeks to support regional initiatives in which culture contributes to economic development, social inclusion, conflict resolution and intercultural dialogue". Special attention should be paid to the fact that the Russian Federation, which is an active participant in the BSEC programs, is excluded from this program. But, within the framework of the Eastern European Partnership, Ukraine receives a resource base for promoting its goals of cultural diplomacy in a country like Moldova, which is included in the BSB CBC regional Black Sea cooperation program.

Already in 2018, when the "New European Agenda for Culture" was written, efforts to organize intercultural dialogue with the participation of EU countries are directly called cultural diplomacy and this area of international activity is given great importance not only in economic or political terms, but also in ensuring national security. Activities in the field of culture are seen as a way to prevent conflicts, as a way to find a consensus for further development:

"With the 2016 Joint Communication 'Towards an EU strategy for international cultural relations', the EU has established a framework for cultural cooperation with partner countries. This is fully in line with the UNESCO 2005 Convention on the Protection and Promotion of the Diversity of Cultural Expressions, to which the EU and all Member States are Parties. The Global Strategy for the European Union's Foreign and Security Policy has identified cultural diplomacy as a new field for EU joined-up external action. The New European Consensus on Development recognizes the role of culture as an important component and enabler.

The Commission, the High Representative of the Union for Foreign Affairs and Security Policy (the High Representative) and their services - including the European External Action Service (EEAS) - fully support ongoing work within the Council to draw up a comprehensive step-by-step approach to international cultural relations. Action by the EU brings synergies and added value, especially in light of the expanded role of EU Delegations. Cultural focal points in EU Delegations are being trained on the cultural dimension of development and external relations, to determine best practices and meet the needs and expectations of local partners.

The New Agenda enables culture to be promoted more effectively as a vector of identity and cohesion, a driver of socio-economic development, and a factor directly nurturing peaceful relations, including through the people-to-people contacts resulting from education and youth projects, with a particular focus on the Western Balkans and Enlargement 
countries. The Commission also plans to use the Agenda to emphasize the cultural dimension of sustainable development and to help implement the UN 2030 Agenda for Sustainable Development"

In 2018, the EU extended the Cultural Partnership Programs for Eastern European Cooperation for a third period until 2022, which implies the development of cooperation in this area for the countries of the Black Sea basin. The general ideas of the "New European Agenda for Culture" are reflected in the Council conclusions on the Work Plan for Culture 2019-2022.

The Work Plan is based on the following guiding principles:

“- Culture has an intrinsic value.

- Culture contributes to sustainable social and economic development.

- Cultural and linguistic diversity is a key asset of the European Union and its protection and promotion are central to cultural policy at European level.

- Cultural mainstreaming requires a holistic and horizontal approach as regards legislation, financing and cross-sectoral cooperation.

- Regular dialogue between Member States, European institutions and civil society as well as thematic cooperation with international organizations create synergies and lead to better results.

- Better governance requires clear responsibilities and engagement by all actors involved.

- Regular monitoring by the Presidency of the Council is necessary to track the progress of the actions.

- Flexibility of the Work Plan for Culture is essential to be able to react to a changing policy environment."

Hence, achieving the strategic goals of public diplomacy of Ukraine by making full use of the opportunities of cultural diplomacy in the Black Sea region should take into account the different status of the countries of this region in relation to the EU. Countries such as Romania and Bulgaria are members of the EU and are covered by the full range of EU cultural programs. Other countries - Armenia, Azerbaijan, Georgia and Moldova - are involved in the Eastern European Partnership program on common terms for Ukraine. However, Ukraine's cultural diplomacy in the Black Sea Basin should also contribute to the fulfillment of the commitments made by the state under the "Association Agreement between Ukraine and the EU". As we can see, cultural diplomacy in the Black Sea region can be clearly pro-European, thanks to various instruments of participation in European cultural programs. For Ukraine, the source of the most powerful resource base for cultural cooperation with the countries of the Black Sea region are two programs - Creative Europe and the BSB CBC program.

\section{Local Level of Ukraine's Cultural Diplomacy of in the Black Sea Region}

The formation of the Black Sea regional cultural identity is facilitated by targeted programs implemented by the European Union within the framework of the implementation of instruments for promoting good-neighborliness and cross-border cooperation. The Black Sea region has been the focus of the European Neighborhood Instruments for Cross-border cooperation (ENI CBC) program since 2007, while the instrument system itself and its ideology were approved by the Council of Europe a year earlier - in 2006.N

The European Neighborhood Support Program already has experience in the implementation of cross-border projects in the Black Sea region, which were encouraged between 2007 and 2013. This EU initiative was continued in a new round of funding for international cooperation projects of the Black Sea countries, which is valid from 2014 to 2020. But it can be argued that, in fact, the program has already been automatically extended, since a competition for grant applications was held in January 2019, the implementation of the ideas of which is expected in the period from 2020 to 2022.

The EU's support for the ideas of transboundary cooperation in the Black Sea basin begins its history simultaneously with the formation of a political vision of regional identity, which was formed in 2007 in the concept of "Black Sea Synergy". However, the current ENI CBC Black Sea Basin Joint Operational Program 2014-2020 has a significant political difference from the previous program: as in the case of the Eastern European Partnership program, the Russian Federation is excluded from the list of participants. Thus, since 2014, there has actually been a significant modification of the regional identity model for countries adjacent to the Black Sea coast, which may have far-reaching consequences for the political, economic and cultural self-determination of this region.

It is also worth paying attention to the fact that large-scale countries invited to participate in this political and economic project of the EU, such as Romania, Turkey, Bulgaria, Ukraine, Greece, can only be represented by specific state zones (territories) directly related to economic and cultural interaction across borders, thanks to the port cities located on the Black Sea coast. The Black Sea basin, in fact, is becoming an interstate space, clearly focused on the embodiment of the 
ideology of cultural and economic regionalization. However, the events related to the situation around the Crimean Peninsula make it extremely difficult to implement the ideas of regional cooperation, including the field of culture.

The first series of projects supported by the ENPI CBC Black Sea Basin Joint Operational Program 2007-2013 was focused on three priorities and a number of specific objectives:

"Priority 1: Supporting cross border partnerships for economic and social development based on common resources

Measure 1.1: Strengthening accessibility and connectivity for new intra- regional information, communication, transport and trade links

Measure 1.2: Creation of tourism networks in order to promote joint tourism development initiatives and traditional products

Measure 1.3: Creation of administrative capacity for the design and implementation of local development policies

Priority 2: Sharing resources and competencies for environmental protection and conservation

Measure 2.1: Strengthening the joint knowledge and information base needed to address common challenges in the environmental protection of river and maritime systems

Measure 2.2: Promoting research, innovation and awareness in the field of conservation and environmental protection for protected natural areas

Measure 2.3: Promoting of cooperation initiatives aimed at innovation in technologies and management of solid waste and wastewater management systems

Priority 3: Supporting cultural and educational networks for the establishment of a common cultural environment in the Basin

Measure 3.1: Promoting cultural networking and educational exchange in the Black Sea Basin communities."

From the report posted on the official website of the program, you can get information that within the framework of the first priority, nine projects were supported, within the second - six projects, and the third priority was implemented in four projects.

For the ENI CBC Black Sea Basin Joint Operational Program 2014-2020, a similar structure of goals and objectives has been retained, but it has undergone a number of changes. The goals have become more generalized and practically oriented. If the first program was more focused on creating a resource base, encouraging joint research and establishing common educational platforms, then the second program is already focusing on developing business programs and supporting joint efforts to protect the natural environment of the Black Sea basin:

"Specific Objective 1 - Promote business and entrepreneurship within the Black Sea Basin

Priority 1.1 Jointly promote business and entrepreneurship in the tourism and cultural sectors

Priority 1.2 Increase cross-border trade opportunities and modernization in the agricultural and connected sectors

Specific Objective 2 - Promote coordination of environmental protection and joint reduction of marine litter in the Black Sea Basin

Priority 2.1 Improve joint environmental monitoring

Priority 2.2 Promote common awareness-raising and joint actions to reduce river and marine litter".

In the context of the discussed topic of cultural diplomacy in the Black Sea region, let us draw attention to the data from the report of the Technical Committee of the Program on Priority 1.1, which is directly related to cultural interaction in the region. Until 2022, 11 projects will be implemented, the main goal of which is the development of cross-border tourism of various directions - associated with the promotion of cultural monuments of the region, green tourism, active tourism. It should be noted that the conditions for applying for financial support from the BSB CBC program are pushing both the development of cultural contacts with member states in the EU (Greece, Romania, Bulgaria), and between countries seeking to coordinate cultural policy and economy with countries EU members (Ukraine, Georgia, Moldova). Interesting in this collaboration is the process of mutual recognition and cultural acceptance of countries with different religious traditions, in which Turkey plays a special role.

International cooperation in the field of culture for the countries of the Black Sea region involves the coordination of fundamental approaches to cultural issues, consensus on the main humanitarian goals of cooperation and the acquisition of the practice of joint implementation of interstate cultural projects. A regional platform for establishing partnerships in the field of culture, in addition to the CBC platform, is also the cultural support program within the framework of the Black Sea Economic Cooperation (BSEC). Although this organization is largely designed to form a common economic 
space, given the modern understanding of the role of culture in international relations, it cannot but be interested in the cultural aspects of cooperation in this region.

As a separate area of cooperation in the Black Sea basin, cultural cooperation acquired institutional status in 2007 with the adoption of the Statement of the Ministers of Culture of the Member States of the Organization of the Black Sea Economic Cooperation (BSEC) (Sounion, 4 July 2007).

Currently, on the official website of the organization, we can find information about plans and implemented projects not only in the field of economics, but also in the field of culture. There, in particular, it is reported that activities in the field of culture are carried out within the framework of the implementation of the 8th goal of the "BSEC Economic Agenda Towards an Enhanced BSEC Partnership", adopted in 2012. This goal is aimed at the development of tourism and protection of cultural heritage.

Plans and results of cooperation concerning the cultural partnership of the BSEC member states are constantly published on the official website of the organization. But, for the most part, these are either declarations of a common vision and intentions of the organization in cultural cooperation, or invitations to international festivals, which are organized in one of the countries on preferential terms for participation in the Black Sea basin.

One of the most interesting ideas formed during the discussion of the common cultural future is the idea of cultural unification of the region based on the study of the cultural heritage of Byzantium and the creation of tourist routes that should demonstrate the value of this heritage. This idea has been discussed for several years in a row and is quite attractive from the point of view of tourism development as a sphere of creative industry.

However, for Ukraine, this topic also has a significant political meaning, as it affects the problem of Crimea, which is associated not only with the modern history of Ukraine as an independent state since 1991. In the ancient Byzantine city of Chersonesos (near modern-day Sevastopol on the Crimean peninsula), Prince (Knyaz) Volodymyr converted to Christianity, making Christianity the official religion of Kievan Rus. Today, a political confrontation between Ukraine and Russia is unfolding in the historical and cultural sphere over the so-called legacy of Kievan Rus. The essence of this dispute concerns the problem of national-historical and territorial foundations of the statehood of Ukraine and Russia. The Russian Federation insists that Kievan Rus is a common foundation of the two nations, and therefore Russia can claim the entire territory owned by the ancient state and not recognize the right to national-cultural and sovereign state independence of Ukraine. Ukraine's position is different - the Russian Federation has its own historical and cultural basis, which is associated with the Mokovsky principality, which emerged several centuries later than the Kiev principality and had its own separate trajectory of political and state development. That is why, at the present historical stage, there are two independent states, and from the point of view of Ukraine, inappropriate talks about the cultural unity and indivisibility of the two nations, which are inspired by Russia. Thus, the BSEC cultural initiatives related to the Byzantine cultural heritage raise such issues, which are obviously a topic for discussion about the cultural meaning of cooperation in the region. This aspect of the Black Sea Partnership is, of course, an aspect that requires the use of cultural diplomacy tools, in which Ukraine is very interested and must take a proactive position.

The leadership of the Ukrainian government in participating in the BSEC activities, which has already been mentioned, may be a testament to the awareness of the value of this platform for political dialogue between countries interested in peace in the region. At least in 2019, after a break, the Ukrainian delegation returned to work in the cultural sector and again began to participate in joint meetings on the development of cultural cooperation in the region, as can be seen from the reports on the official website of the BSEC.

The implementation of common plans will be able to raise cultural cooperation in the Black Sea region to a new level, showing the world both regional identity and the weight of the potential common contribution of the Black Sea cooperation countries to global cultural processes. Despite the fact that most of the countries participating in the Black Sea Economic Cooperation are at the same time the beneficiaries of the Eastern European Partnership program, the configuration of this union is still different from the configuration of the ENI BSB CBC 2014-2020 program operating for the countries of the Black Sea region, which is implemented within the framework of the international cultural EU strategies. European programs for the countries of Eastern Europe today definitely exclude Russia from their number.

Of course, regional cooperation in the field of culture is not limited exclusively to the implementation of projects with grant support to programs for the development of good neighborly relations in Eastern Europe, but these programs are important catalysts for building partnerships. Even if the project does not receive financial support, those who collaborated at the stage of its preparation still have the opportunity to communicate in the future and deepen the partnership within the framework of established contacts. Therefore, Ukraine should reconsider the regional priorities set forth in the "Strategy of Public Diplomacy of the Ministry of Foreign Affairs of Ukraine for 2021-2025" and designate the Black Sea region as a special integral object of cultural diplomacy. 


\section{Bilateral Contacts of Ukraine in the Field of Culture with the Black Sea Basin Countries}

Bilateral contacts between Ukraine and the countries of the region are an additional opportunity to implement the strategic goals of cultural policy in the Black Sea region. Such cooperation has historical foundations and modern achievements. It can also be stated that such cooperation has a developed infrastructure, which is represented by national-cultural centers and consulates located in the Black Sea cities of Ukraine.

On the northern shore of the Black Sea, in addition to Crimea, there are three major cities in Ukraine - Odessa, Mykolaiv and Kherson, which are included in the list of territories covered by the BSB CBC program. However, the regional cultural leaders are the Odessa-city, which is a powerful seaport, and the Odessa Oblast (Odessa region) - the territories that are administratively connected with the Odessa-city. The history and present of Odessa and the Odessa region can be a source of proactive cultural communication in the region, which is associated with the ethno-national history of this region.

At present, in the Odessa region there are large areas of compact residence of Bulgarians (centered in Bolgrad) and Moldovans on the banks of the Danube. The presence of autochthonous ethnic communities of Bulgarians and Modavans is a natural reason for cultural interaction with the countries that are their historical homeland. This territory is located in the south of Odessa region and, obviously, Ukraine participates in the implementation of the EU Strategy for the Danube Region. It is a platform for cross-border cooperation with Romania, Bulgaria and Moldova, which is an additional communication resource for collaboration within the Black Sea Commonwealth, especially since the state of the Danube directly affects the state of the environment in the Black Sea. It is a platform for cross-border cooperation with Romania, Bulgaria and Moldova, which is an additional communication resource for collaboration within the Black Sea Commonwealth, especially since the Danube environment directly affects the state of the environment in the Black Sea. However, the strength of contacts in this region between Ukraine and Romania, Ukraine and Bulgaria has long been maintained at the diplomatic level also, thanks to the active work of the Romanian and Bulgarian consulates in Odessa, which are willing to acquaint Ukrainians with the history and present of their national cultures.

A few years ago, a Turkish consulate appeared in Odessa, which actively supports the Turkish diaspora, which has been growing in the region for several decades in a row. A landmark of cultural cooperation between Ukraine and Turkey was the arrangement of Istanbul Park in the central part of Odessa. All costs were borne by the Turkish side.

In Odessa, another park zone has appeared next to this park - the Greek Park, which was created with the support of Greece. Such proximity of culturally equal public spaces representing Greece and Turkey, given the conflict of these countries in Crete, is a respectable initiative of the Ukrainian city, which is fully invested in the development of tolerance in cultural diplomacy.

Cultural ties with Greece are a special topic for Odessa. The Branch of the Hellenic Foundation for Culture, headquartered in Paris, has been operating in Odessa since 1994. The Foundation aims to implement cultural diplomacy in Ukraine, including the dissemination of knowledge about classical Greek and modern Hellenic's culture and assistance in learning the Greek language. The Foundation is located in a historic building where the Filiki Etairia Society members, which were the leaders of the ideas to liberate Greece from the Ottoman Turkish yoke of oppression, gethered Today, it is one of the most important objects of cultural heritage of Hellenic Republic.

Ethnic communities of Armenians, Georgians and Azerbaijanis have always played a significant role in the history and culture of Odessa. Today, these ethnic diasporas have their own self-governing ethno-cultural organizations, whose activities are focused on preserving the national memory of ethnic communities, supporting national-cultural and religious traditions, and establishing ties with ethnic homelands. By helping these organizations to develop through state programs to support national and ethnic minorities, Ukraine is also making a contribution to the development of cultural diplomacy in the Black Sea region.

Since 1991, the public authorities of the Odessa region have made many efforts at various levels of government to form the Black Sea Commonwealth and to fully involve Ukraine in this initiative. However, at present, no official information resource of Odesa or Odesa Oblast records activities under the Black Sea cooperation programs as a vision of a strategic economic and cultural perspective. The same can be said about Mykolayiv and Kherson. It is possible that such local uncertainty about the interests focused on Black Sea cooperation is the reason why this region has fallen out of the field of view of those who created the Ukraine's Strategy of Public Diplomacy. However, this position is erroneous and needs to be reconsidered.

\section{Conclusions}

Country cooperation in the Black Sea region is a complex and multidimensional process, one of whose most important aspects is culture. Culture, in this case, can be interpreted both as a set of national traditions that determine the originality of each country, and as a space for a modern dialogue on topics, the discussion of which brings peoples closer together. 
The authors of the leading ideas of global cultural policy, the main essence of which is set out in the Convention for the Protection and Promotion of the Diversity of Cultural Expressions, sought to take into account the prospects for the further development of humanity, in which we will communicate more with each other, influence each other more, but preserve the right to individuality.

Considering the "culture factor" as one of the leading factors in the success of Ukraine's public policy in the Black Sea region, we can state the following:

- the basic principles of cultural policy of all countries of the region are in the process of synchronization, thanks to the UN framework conventions in the field of culture;

- the formats of cultural diplomacy in the Black Sea region can be very diverse - from joint cooperation in UNESCO programs to bilateral cultural initiatives;

- all programs and dialogue platforms intended for the countries of the Black Sea region imply the development of cultural diplomacy;

- the countries of the Black Sea region are an important, at the same time, object and subject of European cultural policy;

- the Eastern European Partnership program makes a significant contribution to the process of cultural rapprochement between the EU countries and the countries participating in the Black Sea Cooperation;

- the development of cultural diplomacy in the Black Sea region can bring new aspects to the process of modern national-cultural self-identification of Ukraine;

- the creation of a regional cultural cluster can contribute to solving the difficult political situation in the Black Sea basin associated with the status of the Crimean Peninsula.

Cultural diplomacy and international cooperation in the field of culture are today topics for economic and political forums, for forums on international security and the resolution of local conflicts. By developing cultural diplomacy in the Black Sea region, Ukraine can obtain an additional resource for resolving the military conflict that has arisen and continues with the active participation of the Russian Federation. From a strategic perspective, the development of multi-format cultural cooperation between countries in the Black Sea basin should be the ultimate goal of both political and economic interaction in this region.

\section{References}

A

New

European

Agenda

for

Culture.

(2018)

URL

https://www.cultureinexternalrelations.eu/cier-data/uploads/2018/06/commission_communication_a_new_europea n_agenda_for_culture_2018.pdf

Association Agreement between the European Union and Ukraine 。 (2014) URL https://www.kmu.gov.ua/en/yevropejska-integraciya/ugoda-pro-asociacyu

Black Sea Basin Cross Border Cooperation. Official site. URL https://blacksea-cbc.net/programme/programme-documents/

Black Sea Economic Cooperation. Official site. URL http://www.bsec-organization.org/

Convention for the Protection and Promotion of the Diversity of Cultural Expressions (2005). URL https://en.unesco.org/creativity/convention/texts

Convention for the Safeguarding of the Intangible Cultural Heritage. (2003). URL https://ich.unesco.org/en/convention

Council conclusions on the Work Plan for Culture 2019-2022. (2018) URL http://data.consilium.europa.eu/doc/document/ST-13948-2018-INIT/en/pdf

International Center for Black Sea Studies. Official site. URL https://icbss.org/

President of Ukraine. Official site (23.03.2021). Volodymyr Zelensky signed a law ratifying the amendment to Article 24 of the BSEC Statute. URL https://www.president.gov.ua/news/volodimir-zelenskij-pidpisav-zakon-yakim-ratifikuyetsya-popr-67301

Public diplomacy strategy Ministry of Foreign Affairs of Ukraine for 2021-2025 (2021) URL https://mfa.gov.ua/storage/app/sites/1/\%D0\%A1\%D1\%82\%D1\%80\%D0\%B0\%D1\%82\%D0\%B5\%D0\%B3\%D1\% 96\%D1\%97/public-diplomacy-strategy.pdf

Statement of the Ministers of Culture of the Member States of the Organization of the Black Sea Economic Cooperation (2007) URL http://www.bsec-organization.org/areas-of-cooperation/culture/statements-declaration

The Lisbon Treaty. The Readable Version. Third edition. (2009) URL http://en.euabc.com/upload/books/lisbon-treaty-3edition.pdf 
Towards an EU strategy for international cultural relations. (2016). URL https:/eur-lex.europa.eu/legal-content/EN/TXT/PDF/?uri=CELEX:52016JC0029\&from=EN

UKRINFORM. (27.01.2021) Ukraine continues to fight for the post of BSEC Secretary General - Deputy Minister of Foreign Affairs.

URL https://www.ukrinform.ua/rubric-polytics/3179379-ukraina-prodovzue-borotbu-za-posadu-genseka-oces-zastupnik -glavi-mzs.html

UNESCO: Diversity of Cultural Expression. UNESCO Member States reassess the role of culture in the global economy (2019) URL https://en.unesco.org/creativity/news/unesco-member-states-reassess-role-culture-global

UNESCO Culture for Development Indicators. Methodology Manual. (2012) URL https://en.unesco.org/creativity/sites/creativity/files/cdis_methodology_manual_0_0.pdf

UNESCO Culture for Development Indicators: Ukraine's Technical Report (2017) URL https://www.culturepartnership.eu/upload/editor/2017/2017/CDIS\%20Ukraine\%20Technical\%20Report.pdf

\section{Copyrights}

Copyright for this article is retained by the author(s), with first publication rights granted to the journal.

This is an open-access article distributed under the terms and conditions of the Creative Commons Attribution license which permits unrestricted use, distribution, and reproduction in any medium, provided the original work is properly cited. 